\title{
Reversible Video Steganografi Menggunakan Metode Improved Reduced Difference Expansion dan Analisis Gray Level Co-occurrence Matrix
}

\author{
Dicky Irwanto, Tohari Ahmad, dan Hudan Studiawan, \\ Teknik Informatika, Fakultas Teknologi Informasi, Institut Teknologi Sepuluh Nopember (ITS) \\ Jl. Arief Rahman Hakim, Surabaya 60111 Indonesia \\ e-mail: tohari@if.its.ac.id, hudan@if.its.ac.id, dicky.doktergigi@gmail.com
}

\begin{abstract}
Abstrak-Saat ini penelitian mengenai steganografi telah banyak dilakukan, namun metode yang digunakan hanya berfokus pada media citra. Dimana metode ini memiliki kelemahan yaitu media yang digunakan media penyisipan tidak dapat dikembalikan. Tidak hanya itu berkas gambar juga memiliki kelemahan terbatasnya jumlah pixel yang tersedia pada suatu citra. Karena kelemahan tersebut perlunya metode yang bersifat reversible serta media selain citra untuk meningkatkan fleksibilitas dari proses steganografi.

Untuk meningkatkan fleksibilitas proses steganografi salah satunya dapat dilakukan menggunakan media video sebagai cover serta menggunakan metode IRDE (Improved Reduced Difference Expansion) yang dikombinasikan dengan metode analisis GLCM (Gray Level Co-occurrence Matrix) dan metode distribusi pesan secara intraframe dan interframe. Tujuan penggunaan kombinasi metode tersebut adalah untuk meningkatkan jumlah kapasitas pesan yang disisipkan serta meminimalkan jumlah frame yang digunakan pada proses encode.

Hasil dari uji coba proses steganografi dengan kombinasi metode tersebut dapat meningkatkan jumlah payload yang dapat disisipkan hingga 59\% dibandingkan dengan metode distribusi intraframe dan $146 \%$ dibandingkan dengan metode distribusi interframe pada media yang diujikan. Fitur pemilihan kandidat yang baik pada metode distribusi intraframe dan interframe (kombinasi) yaitu fitur pemilihan kandidat bedasarkan jumlah layer untuk jumlah payload $\leq 1034408$ bit dan pemilihan bedasarkan nilai quadratic means perbedaan pixel untuk jumlah payload > 1034408 bit.
\end{abstract}

Kata Kunci-Steganografi, Video, Improved Reduced Difference Expansion, Gray Level Co-occurence Matrix.

\section{PENDAHULUAN}

$\mathrm{B}$ ERKEMBANGNYA teknologi keamanan informasi memberikan dampak besar dari distribusi pengiriman berkas digital. Ada kalanya berkas digital yang dikirimkan bersifat rahasia dan confidential, seperti data catatan militer, kesehatan pasien, dan data keuangan. Sehingga harus dipastikan data tersebut hanya diketahui oleh pihak yang berhak. Salah satu metode yang dapat digunakan untuk menjaga kerahasiaan adalah steganografi.

Penelitian pada bidang steganografi telah banyak dilakukan khususnya pada media citra, audio maupun video. Beberapa metode yang telah pernah diajukan yaitu Low Bit Encoding, Echo Hiding, Spread Spectrum, Phase Coding [1], dan juga menggunakan transformasi wavelet [2]. Namun, dari metode tersebut memiliki kelemahan yaitu berkas cover tidak dapat dikembalikan ke bentuk semula (irreversible).

Untuk mendapatkan kembali berkas cover dan berkas payload, perlunya menggunakan metode-metode yang bersifat reversible. Salah satu metode yang dapat digunakan adalah Difference Expansion (DE) [3], Reduced Difference Expansion (RDE), dan Improved Reduced Difference Expansion yang diusulkan oleh $\mathrm{Hu}$ Yi [4].

Metode Improved Reduced Difference Expansion (IRDE) merupakan metode hasil modifikasi metode Reduced Difference Expansion [4]. Dengan menggunakan metode ini sebuah data sisipan (payload) dan berkas video (cover) dapat dikembalikan seutuhnya tanpa adanya distorsi [4]. Pada paper sebelumnya metode Improved Reduced Difference Expansion sudah diterapkan pada media citra sebagai cover. Penggunaan media citra menggunakan metode IRDE menyebabkan keterbatasan jumlah pixel yang akan disisipkan dikarenakan pada metode IRDE terdapat batasan jumlah kandidat yang lebih sempit dibandingkan dengan metode DE atau RDE.

Pada tugas akhir ini kami mencoba menerapkan metode Improved Reduced Difference Expansion yang sebelumnya diterapkan pada media citra akan dicoba diterapkan pada media video dengan menambah beberapa modifikasi agar dapat diterapkan. Beberapa modifikasi yang harus dilakukan yaitu perubahan struktur location map (LM) dan penambahan metode distribusi pesan dengan menggunakan metode jumlah nilai quadratic means perbedaan pixel, metode variance, jumlah layer yang digunakan dan jumlah bit payload yang dapat disisipkan. Serta untuk meningkatkan jumlah pesan yang disisipkan distribusi pesan akan dilakukan melalui dua cara, yaitu distribusi pesan secara single frame (intraframe) dan distribusi pesan antar frame (interframe).

\section{METODE PENELITIAN}

Steganografi video dengan metode Improved Reduced Differenced Expansion secara garis besar terdapat dua tahapan pemrosesan yaitu tahap encoding dan decoding. Perbedaan batasan tahap yang kami gunakan pada paper ini dengan paper sebelumnya [4] yaitu terletak pada modifikasi nilai pixel dalam keadaan nilai location map adalah 0 maka tidak adanya modifikasi nilai pixel yang dilakukan sedangkan disaat nilai location map adalah 1 maka modifikasi pixel dilakukan. Hal 
ini dikarenakan reduksi terbaik terletak pada keadaan location map adalah 1 [4].

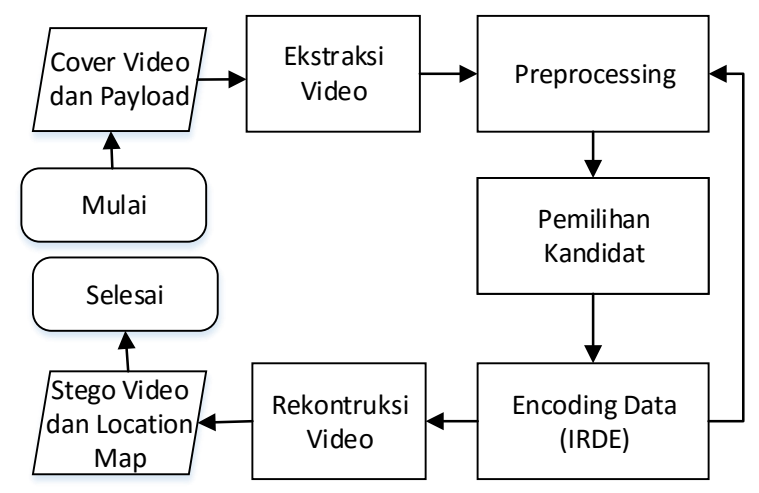

Gambar 1. Skema Proses Encoding

Proses pada tahap encoding terdiri empat tahapan yaitu: proses preprocessing, proses pemilihan kandidat secara intraframe atau interframe, proses penyisipan payload kedalam kandidat menggunakan metode IRDE, dan proses pembuatan location map bedasarkan data yang disisipkan Gambar 1. Untuk proses tahap decoding terdiri dari dua tahapan yaitu: proses ektraksi location map dan proses pengembalian payload dan cover menggunakan metode IRDE Gambar 3.

Berbeda dengan metode IRDE sebelumnya yang menggunakan distribusi secara horisontal dan vertikal Gambar 2, pada metode yang diajukan proses distribusi payload dilakukan dua cara yaitu: distribusi payload pada satu frame (intraframe) Gambar 2 (a) dan distribusi payload yang melalui frame yang berbeda (interframe) Gambar 2 (b).

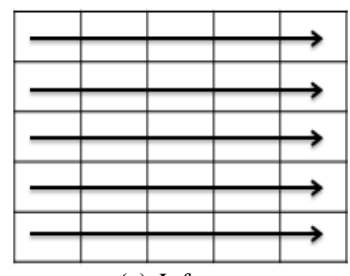

(a) Inframe
Gambar 2. Distribusi Payload (b) Interframe

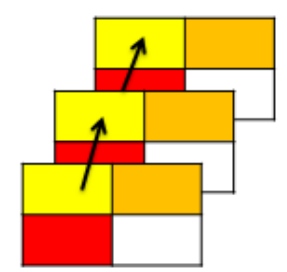

Untuk mendapatkan nilai total distribusi payload dapat menggunakan (1).

$$
s=(\text { width } \times \text { height })+\text { total frame }
$$

Contoh, jika kita menggunakan video dengan panjang 10 detik berukuran 512 x 512 dengan jumlah frame perdetik 30 FPS. Maka jumlah distribusi payload:

$$
s=(512 \times 512)+(30 \times 10)=262444 \text { kandidat }
$$

Pada (2) terlihat bahwa dengan kombinasi antara intraframe dan interframe jumlah kandidat lebih banyak dibandingkan menggunakan salah satu metode tersebut. Untuk mendukung kombinasi penggunaan Intraframe dan Interframe dalam proses steganografi, metode yang digunakan dalam proses encode atau decode harus mendukung adanya proses layering.

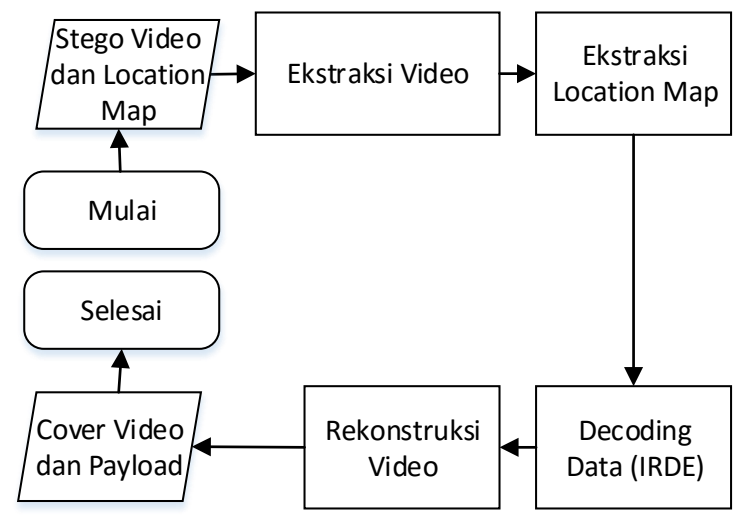

Gambar 3. Skema Proses Decoding

A. Encode

1) Preprocessing: tahap preprocessing merupakan tahap perhitungan nilai fitur pada metode yang diajukan. Perhitungan nilai fitur kandidat pada metode yang diajukan menggunakan empat cara yaitu: perhitungan berdasarkan jumlah layer setiap kandidat, perhitungan bedasarkan nilai variance GLCM setiap kandidat, perhitungan bedasarkan jumlah data yang dapat disisipkan pada kandidat, dan perhitungan bedasarkan nilai quadratic means perbedaan pixel kandidat. Perhitungan nilai fitur pertama yaitu bedasarkan jumlah layer merupakan proses perhitungan jumlah layer yang dimiliki pada setiap kandidat. Jumlah layer setiap kandidat akan bertambah jika kandidat tersebut digunakan untuk proses encoding. Skema proses penyisipan bedasarkan jumlah layer terdapat pada Gambar 3. Untuk perhitungan kedua yaitu bedasarkan nilai variance merupakan proses penetapan kandidat terbaik dan perhitungan variance setiap kandidatnya. Indikator kandidat terbaik pada proses encoding yaitu kandidat memiliki jumlah payload yang dapat disisipkan (Total $l_{\text {kandidat }}$ ) terbanyak dan memiliki total perbedaan nilai modifikasi pixel terendah. Nilai Total $l_{\text {kandidat }}$ dan pada proses preprocessing bedasarkan nilai variance dapat dihitung melalui (3) hingga (8).

$$
h_{\mathrm{i}}=\mid \text { pixel }_{\mathrm{i}}-\text { pixel }_{\mathrm{i}+1} \mid
$$$$
n=\left\lfloor\log _{2} h_{\mathrm{i}}\right\rfloor
$$

flog $_{\mathrm{i}}=\left\{\begin{array}{l}0 \text { if } 2 \times 2^{n-1} \leq h_{\mathrm{i}} \leq 3 \times 2^{n-1}-1 \\ 1 \text { if } 3 \times 2^{n-1} \leq h_{\mathrm{i}} \leq 4 \times 2^{n-1}-1\end{array}\right.$

$$
\text { Total }_{\text {kandidat }}=\sum_{\mathrm{i}=1}^{\text {nkandidat }_{\text {ka }}} \text { flag }_{\mathrm{i}}
$$

$$
\begin{aligned}
& R_{\text {kandidat }}=\sum_{i=1}^{n_{\text {kandidat }}} x_{i}-\left(l_{i}+h_{i}^{i}\right) \text { if flag } \log _{i}=1 \\
& L_{\text {kandidat }}=\sum_{i=1}^{n_{\text {kandidat }}} y_{i}-\left(l_{i}-h_{i}^{i}\right) \text { if flag } g_{i}=1
\end{aligned}
$$


Nilai $n_{\text {handidat }}$ merupakan nilai jumlah blok pada kandidat interframe atau intraframe. Sedangkan untuk nilai $x$ merupakan nilai terbesar dari blok pixel dan nilai $y$ merupakan nilai terendah dari blok pixel. Untuk nilai $l_{i}$ merupakan nilai rata-rata dari pixel dalam blok. Untuk nilai $h_{\mathrm{i}}^{g}$ merupakan nilai hasil reduksi pada metode IRDE. Untuk $R_{\text {kandidat dan }}$ $L_{\text {kandidat }}$ merupakan nilai total kenaikan atau penurunan pixel setelah dimodifikasi. Kemudian setelah mendapatkan nilai Total $l_{\text {kandidat }}, L_{\text {kandidat }}$, dan $R_{\text {kandidat }}$ tahap selanjutnya yaitu menghitung nilai rata-rata setiap kandidat dan pilih kandidat yang memiliki rata-rata terendah. Pemilihan ini bertujuan untuk memilih kandidat yang terbaik dengan memiliki nilai $h$ yang kecil. Rata-rata setiap kandidat dapat dihitung dengan (9).

$$
\mu_{\text {kandidat }}=\frac{R_{\text {kandidat }}+L_{\text {kandidat }}}{\text { Total }}
$$

Tahap selanjutanya yaitu menghitung nilai variance setiap kandidat dengan metode GLCM. Metode analisis GLCM yang digunakan adalah variance. Untuk kerapatan dan sudut yang digunakan yaitu kerapatan satu pixel dan sudut yang digunakan adalah $0^{\circ}$. Pencarian nilai variance dapat menggunakan (11).

$$
\begin{gathered}
\mu=\frac{1}{M \times N} \sum_{i=1}^{M} \sum_{j=1}^{N} P_{i j} \\
\text { Variance }=\frac{1}{M \times N} \sum_{i=1}^{M} \sum_{j=1}^{N}\left(P_{i j}-\mu\right)^{2}
\end{gathered}
$$

Nilai $P_{i j}$ pada (11) merupakan nilai dari matrik GLCM, untuk nilai nilai $M$ dan $N$ merupakan nilai ukuran dari matrik GLCM. Perhitungan nilai variance setiap kandidat nantinya digunakan untuk membandingkan fitur kandidat yang sebelumnya terdipilih dengan kandidat lain. Tahap selanjutnya yaitu memilih kandidat yang memiliki nilai $\mu_{\text {kandidat }}$ terendah, kandidat tersebut merupakan kandidat terbaik yang nantinya akan dibandingkan nilai variancenya dengan kandidat lain.

Perhitungan nilai fitur yang ketiga yaitu perhitungan preprocessing bedasarkan nilai root mean square (RMS) kenaikan dan penurunan nilai modifikasi pixel. Sebelum menghitung nilai RMS perlunya mengetahui nilai kuadarat jumlah kenaikan atau penurunan nilai pixel dan jumlah total kapasitas, hal ini dilakukan untuk menghitung kemungkinan jumlah noise pada pixel frame setelah disisipkan dan jumlah total payload yang dapat disisipkan pada setiap kandidat. Persamaan yang digunakan untuk menentukan nilai kuadrat jumlah kenaikan atau penurunan dapat dengan menggunakan (12), (13), dan untuk menentukan jumlah total payload yang dapat disisipkan menggunakan (6).

$$
R_{\text {kandidat }}{ }^{2}=\sum_{i=1}^{n_{\text {kandidat }}}\left(x_{i}-\left(l_{i}+h_{i}^{h}\right)\right)^{2} \text { if flag } \log _{\mathrm{i}}=1
$$

$L_{\text {kandidat }}{ }^{2}=\sum_{i=1}^{n_{\text {kandidat }}}\left(y_{i}-\left(l_{i}-h_{i}^{j}\right)\right)^{2}$ if flag $g_{i}=1$

Setelah nilai $R_{\text {kandidat }}{ }^{2}, L_{\text {kandidat }}{ }^{2}$ dan nilai Total $l_{\text {kandidat }}$ didapatkan, selanjutnya menghitung nilai RMS pada setiap kandidat. Perhitungan RMS dapat menggunakan (14).

$$
Q_{\text {kandidat }}=\sqrt{\frac{R_{\text {kandidat }}{ }^{2}+L_{\text {kandidat }}{ }^{2}}{\text { Total }_{\text {kandidat }}}}
$$

Perhitungan nilai fitur yang keempat yaitu perhitungan preprocessing bedasarkan jumlah kapasitas payload yang dapat disisipkan. kenaikan dan penurunan nilai modifikasi pixel. Perhitungan jumlah kapasitas payload dapat dihitung menggunakan (6).

Setelah menghitung fitur yang digunakan tahap selanjutnya yaitu pemilihan kandidat. Pemilihan kandidat merupakan proses pemilihan kandidat yang sesuai dengan batasanbatasan pengujian dan bedasarkan fitur yang digunakan. Batasan-batasan pemilihan setiap kandidat sebagai berikut:

1. Nilai PSNR dari setiap frame $>35 \mathrm{~dB} .35 \mathrm{~dB}$ merupakan nilai tengah Dikarenakan jika nilai PSNR < 30 termasuk frame yang bersifat low quality dan jika nilai PSNR $>40$ termasuk frame yang bersifat high quality [5].

2. Batasan jumlah payload yang disimpan pada setiap kandidatnya adalah $5 \%$.

Jika setiap kandidat memenuhi batasan-batasan tersebut selanjutnya yaitu setiap kandidat akan dipilih sesuai dengan keadaan fiturnya. Detail pemilihan kandidat bedasarkan fitur sebagai berikut:

1. Fitur bedasarkan jumlah layer, kandidat yang dipilih merupakan kandidat yang memiliki jumlah layer terendah.

2. Fitur bedasarkan nilai variance, kandidat yang dipilih merupakan kandidat yang memiliki difference variance terhadap kandidat yang dipilih pada tahap preprocessing.

3. Fitur bedasarkan nilai Root Mean SquareI, kandidat yang dipilih merupakan kandidat yang memiliki nilai RMS terendah.

4. Fitur bedasarkan jumlah kapasitas payload, kandidat yang dipilih merupakan kandidat yang memiliki jumlah kapasitas payload terbanyak.

2) Encode payload: Tahap encode payload merupakan tahap penyisipan payload ke dalam cover. Metode yang digunakan pada tahap ini adalah metode IRDE karena metode tersebut mendukung adanya layering frame [4] serta dapat mengembalikan data cover dan payload secara utuh tanpa distorsi [4]. Cara kerja metode IRDE adalah membandingkan dua buah pixel yang saling bertetangga.

3) Pembuatan location map: location map merupakan data yang menyimpan lokasi peletakan payload ke dalam cover. Pembuatan location map bertujuan untuk mengembalikan data payload dan cover ke bentuk semula. Setiap metode steganografi biasanya mendefenisikan location map berbedabeda. Pada Location Map metode yang kami ajukan, terdapat beberapa perbedaan dengan metode IRDE yang sebelumnya. location map pada metode IRDE sebelumnya mendefinisikan 
1 untuk keadaan pixel disisipkan dan 0 untuk pixel yang tidak disisipkan, namun untuk metode yang kami ajukan terdapat bagian yang merepresentasikan inframe atau interframe, lokasi penyisipan data serta keadaan pixel yang disisipkan. Perhitungan tersebut dapat dilihat pada (15) dan (16).

$m=\left\{\begin{array}{c}\text { length } * \text { width } \text {,if length } * \text { width }>\text { total frame } \\ \text { total frame, if length } * \text { width } \leq \text { total frame }\end{array}\right.$

Persamaan (15) merupakan persamaan yang digunakan untuk mendapatkan panjang bit lokasi penyisipan payload. Kemudian hasil dari (15) akan dikombinasikan dengan bagian yang merepresentasikan inframe atau interframe dan panjang keadaan perubahan pixel, total panjang location map direpresentasikan pada (16).

$$
L M_{\text {handidat }}=1+\left\lceil\log _{2} m\right\rceil+\text { Length Data Encode }
$$

\section{B. Decode}

1) Ekstraksi Stego Video dan Location Map: Sama seperti tahap encode, proses ektraksi video dilakukan untuk mengambil informasi dan mengektraksi video menjadi frame. Untuk ektraksi location map dapat dilihat pada Gambar 4.

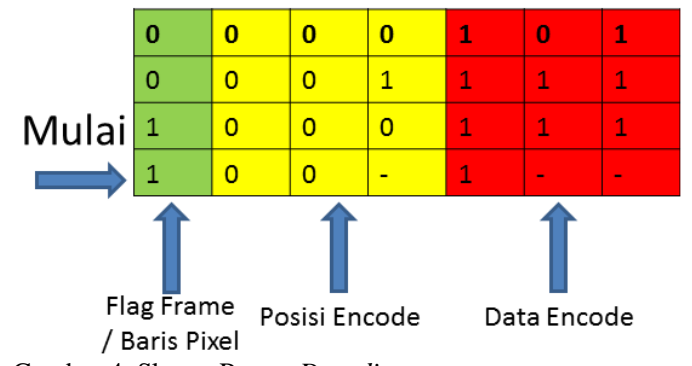

Gambar 4. Skema Proses Decoding

Pada proses ektraksi location map pembacaan data harus dilakukan pada baris yang paling bawah. Hal ini dilakukan karena penggunaan konsep layering pada proses encode. Setelah tahap pembacaan data, setiap baris location map akan diekstraksi menjadi tiga bagian yaitu bagian jenis distribusi, posisi kandidat, dan informasi penyisipan.

2) Decode Stego Video: Tahap decode stego merupakan tahap pengembalian payload dan cover ke bentuk semula. Metode yang digunakan pada tahap ini adalah Metode IRDE yang diimplementasikan oleh Hu Yi [4]. Sebelum melakukan decode perlunya informasi terkait posisi penyisipan dan teknik penyisipan secara inframe atau interframe.

\section{HASIL UJI COBA}

Data yang digunakan untuk uji coba implementasi sistem steganografi ini adalah berkas video dengan ekstensi avi dengan batasan kompresi yang digunakan pada video adalah HuffyUV dan bertipe grayscale dan untuk payload yang digunakan berformat .TXT. Detail uji coba ditunjukkan pada Tabel 1 dan Tabel 2.

Data uji video Tabel 1 merupakan data uji standar pada bidang kompresi dan steganografi yang dapat diunduh pada halaman http://media.xiph.org/video/derf/.
Tabel 1

Dataset Video

\begin{tabular}{cccc}
\hline \hline Nama Cover & $\begin{array}{c}\text { Resolusi } \\
\text { Frame }\end{array}$ & $\begin{array}{c}\text { Total } \\
\text { Frame }\end{array}$ & $\begin{array}{c}\text { Durasi Cover } \\
\text { Video (s) }\end{array}$ \\
\hline Video (.avi) & $352 \times 240$ & 115 & 3 \\
Garden & $176 \times 144$ & 130 & 8 \\
Football & $352 \times 288$ & 150 & 5 \\
Bus & $352 \times 240$ & 150 & 5 \\
Tennis &
\end{tabular}

Tabel 2

Dataset Payload

\begin{tabular}{cc}
\multicolumn{2}{c}{ Dataset Payload } \\
\hline \hline Nama Payload (.txt) & Panjang Data (bit) \\
\hline asyoulik & 1034408 \\
asyoulik3 & 3103224 \\
asyoulik4 & 4137632 \\
\hline \hline
\end{tabular}

\section{A. Skenario Uji Coba 1}

Skenario uji coba 1 merupakan proses pengujian perbandingan nilai batasan kandidat untuk proses pemilihan kandidat. Proses penentapan batasan kandidat dilakukan melalui dua cara yaitu penetapan batasan kandidat bedasarkan jumlah payload yang dapat disisipkan pada kandidat dan bedasarkan waktu eksekusi proses uji coba penyisipan. Batasan yang digunakan pada uji coba ini sebesar 5\%, 10\%, $15 \%$, dan $20 \%$. Hasil uji coba ditunjukkan pada Gambar 5 dan Gambar 6.

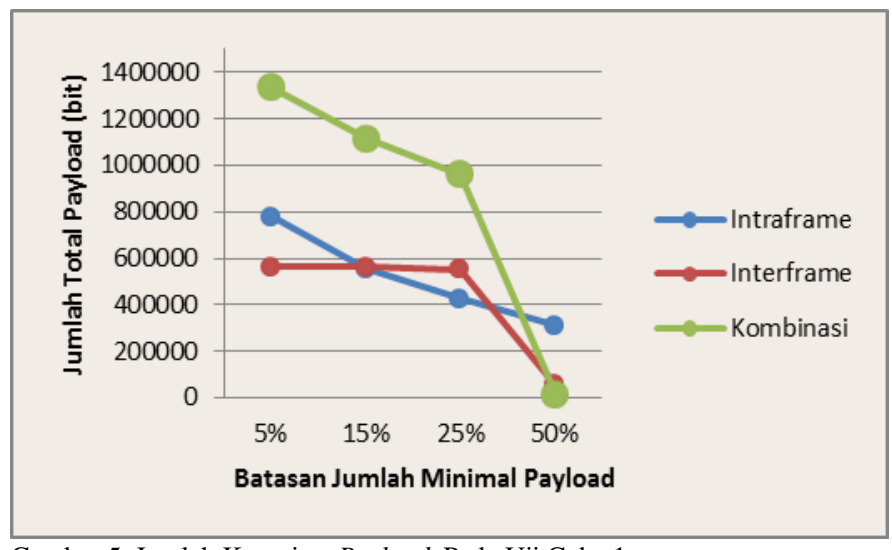

Gambar 5. Jumlah Kapasitas Payload Pada Uji Coba 1

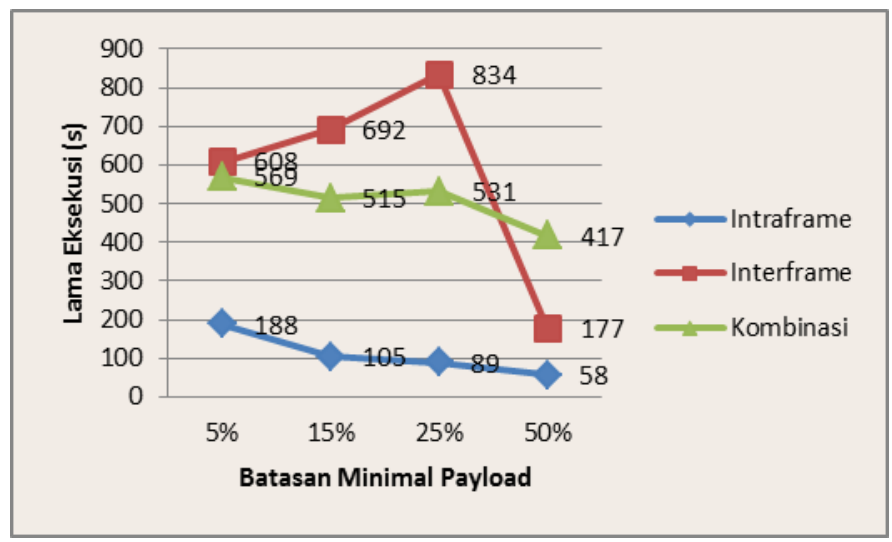

Gambar 6. Lama Waktu Eksekusi Pada Uji Coba 1

Hasil uji coba pertama yakni bedasarkan pada jumlah payload. Hasil uji coba pertama terlihat bahwa peningkatan batasan minimal payload berpengaruh dalam kapasitas jumlah payload. Semakin tingginya batasan yang digunakan maka 
semakin sedikitnya payload yang dapat disisipkan pada setiap kandidat. Pada Gambar 5 dan Gambar 6 terlihat juga bahwa penentuan batasan minimal payload berpengaruh pada lama eksekusi pada program. Hal ini berkaitan dengan semakin tingginya batasan minimal payload maka semakin banyaknya kandidat yang dibutuhkan. Dan semakin banyaknya kandidat yang digunakan maka berpengaruh pada lama eksekusi.

\section{B. Skenario Uji Coba 2}

Skenario uji coba 2 merupakan proses perbandingan kapasitas encoding secara intraframe, interframe, dan kombinasinya. Hasil perbandingan kapasitas encoding ditunjukkan pada Tabel 3 hingga Tabel 6.

Tabel 3.

Kapasitas Payload Bedasarkan Fitur Quadratic Means

\begin{tabular}{cccc}
\hline \hline \multirow{2}{*}{$\begin{array}{c}\text { Nama } \\
\text { Video }\end{array}$} & \multicolumn{2}{c}{ Kapsitas Payload (Fitur Quadratic Means) } \\
\cline { 2 - 4 } & Distribusi & Distribusi & Distribusi \\
& Intraframe & Interframe & Kombinasi \\
\hline Football & 778360 & 561941 & 1235111 \\
Bus & 4033592 & 2685272 & 4137632 \\
Garden & 2675822 & 1633604 & 3908237 \\
Tennis & 3346781 & 1685061 & 4137632 \\
\hline \hline
\end{tabular}

Tabel 4.

Kapasitas Payload Bedasarkan Fitur Variance

\begin{tabular}{cccc}
\hline \hline \multirow{2}{*}{ Nama } & \multicolumn{3}{c}{ Kapsitas Payload (Fitur Variance) } \\
\cline { 2 - 4 } Video & Distribusi & Distribusi & Distribusi \\
& Intraframe & Interframe & Kombinasi \\
\hline Football & 778481 & 561941 & 1235421 \\
Bus & 4033450 & 2685272 & 4137632 \\
Garden & 2676439 & 1633604 & 3924446 \\
Tennis & 3348283 & 1685061 & 4137632 \\
\hline \hline
\end{tabular}

Tabel 5.

Kapasitas Payload Fitur Kapasitas Payload

\begin{tabular}{|c|c|c|c|}
\hline \multirow{2}{*}{$\begin{array}{l}\text { Nama } \\
\text { Video }\end{array}$} & \multicolumn{3}{|c|}{ Kapsitas Payload (Fitur Jumlah Payload) } \\
\hline & $\begin{array}{l}\text { Distribusi } \\
\text { Intraframe }\end{array}$ & $\begin{array}{l}\text { Distribusi } \\
\text { Interframe }\end{array}$ & $\begin{array}{c}\text { Distribusi } \\
\text { Kombinasi }\end{array}$ \\
\hline Football & 778360 & 561941 & 1234728 \\
\hline Bus & 4033450 & 2685272 & 4137632 \\
\hline Garden & 2676733 & 1633604 & 3908237 \\
\hline Tennis & 3346781 & 1685061 & 4137632 \\
\hline
\end{tabular}

Tabel 6.

Kapasitas Payload Fitur Jumlah Layer

\begin{tabular}{cccc}
\hline \hline \multirow{2}{*}{$\begin{array}{c}\text { Nama } \\
\text { Video }\end{array}$} & \multicolumn{3}{c}{ Kapsitas Payload (Fitur Layer) } \\
\cline { 2 - 4 } & Distribusi & Distribusi & Distribusi \\
& Intraframe & Interframe & Kombinasi \\
\hline Football & 778972 & 561941 & 1235736 \\
Bus & 4033550 & 2685272 & 4137632 \\
Garden & 2676428 & 1633604 & 3924532 \\
Tennis & 3348798 & 1685061 & 4137632 \\
\hline \hline
\end{tabular}

Pada Tabel 3 hingga Tabel 6 terlihat bahwa jumlah payload yang dapat disisipkan pada metode distribusi kombinasi lebih besar dibandingkan dengan metode distribusi secara interframe dan intraframe.

\section{Skenario Uji Coba 3}

Skenario uji coba 3 merupakan proses uji coba perbandingan nilai PSNR dengan menggunakan metode distribusi payload secara intraframe dan interframe (kombinasi). Uji coba akan dilakukan pada empat fitur yaitu fitur pemilihan kandidat bedasarkan nilai quadratic means, nilai variance, kapasitas payload yang dapat disisipkan, dan jumlah layer. Hasil uji coba skenario 3 ditunjukkan pada Gambar 7 hingga Gambar 10.

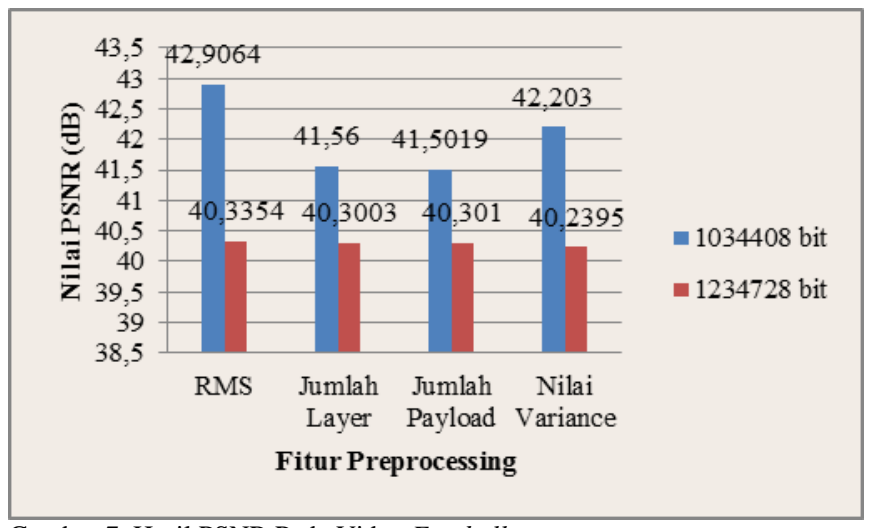

Gambar 7. Hasil PSNR Pada Video Football

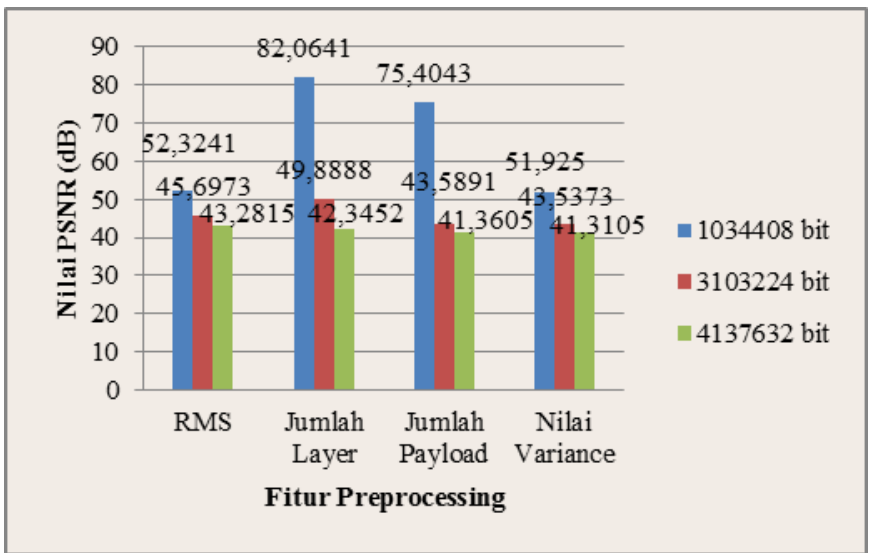

Gambar 8. Hasil PSNR Pada Video Bus

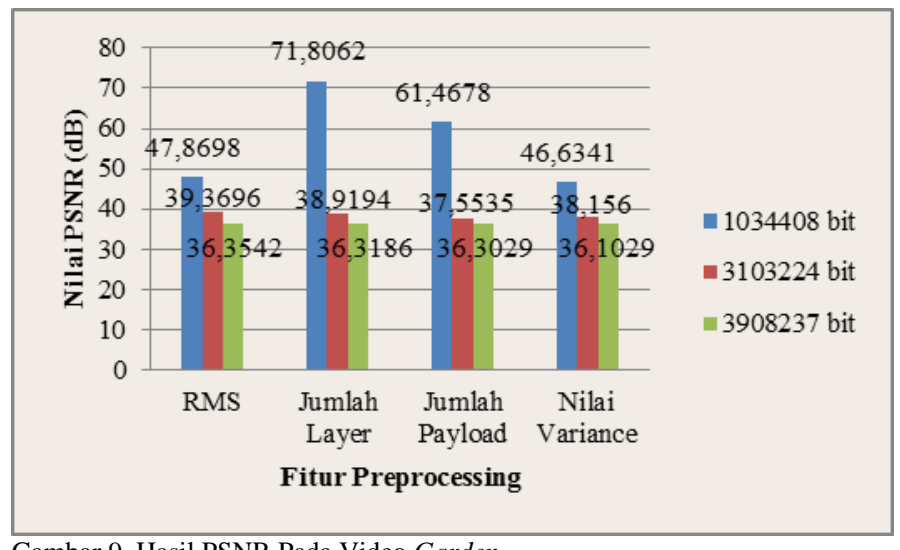

Gambar 9. Hasil PSNR Pada Video Garden 


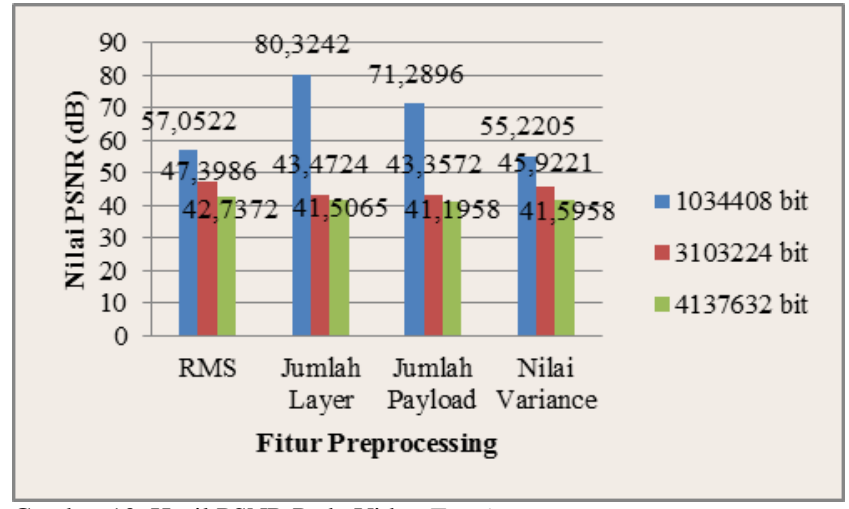

Gambar 10. Hasil PSNR Pada Video Tennis

Berdasarkan hasil uji coba skenario 3 fitur yang paling terbaik dalam melakukan preprocessing adalah fitur penyisipan menggunakan metode pemilihan kandidat bedasarkan jumlah layer setiap kandidat pada jumlah payload $\leq 1034408$ bit dan untuk jumlah payload > 1034408 fitur terbaik dalam pemilihan kandidat menggunakan preprocessing bedasarkan nilai Root Mean Square (Quadratic Means).

\section{KESIMPULAN}

Bedasarkan hasil uji coba steganografi pada video dengan metode IRDE dan dikombinasikan dengan distribusi secara interframe dan intraframe dan pemilihan kandidat sesuai fitur didapatkan kesimpulan sebagai berikut:

1. Uji coba proses encode menggunakan skema distribusi secara interframe dan intraframe memperlihatkan peningkatan jumlah kapasitas yang signifikan.

2. Bedasarkan hasil uji coba, fitur pemilihan kandidat yang menghasilkan nilai PSNR dan jumlah payload terbaik pada distribusi payload secara kombinasi adalah fitur pemilihan kandidat bedasarkan jumlah layer pada jumlah payload 1034408 bit dengan nilai PSNR maksimal 82,0641 dB yang diujikan pada cover Bus dan fitur pemilihan kandidat bedasarkan nilai quadratic means perbedaan pixel pada jumlah payload > 1034408 bit dengan nilai PSNR maksimal 47,3986 dB yang diujikan pada cover Tennis.

\section{DAFTAR PUSTAKA}

[1] Bilal, I., Roj, M.S., Kumar, R., Mishra, P.K., 11-13 Dec. 2014,"Recent advancement in audio steganography", Parallel, Distributed and Grid Computing (PDGC), 2014 International Conference, 402-405.

[2] Santosa, R.A., Bao, P., 8-10 Juni 2005,"Audio-to-image wavelet transform based audio steganography", ELMAR, 2005. 47th International Symposium, 209-212.

[3] Tian, J., Aug. 2003, "Reversible data embedding using a difference expansion", Circuits and Systems for Video Technology, IEEE Transactions, 13, 8: 890-896.

[4] Yi, H., Wei, S., Hou, J., Aug. 2009, "Improved Reduced Difference Expansion Based Reversible Data Hiding Scheme for Digital Images", Electronic Measurement \& Instruments, ICEMI'09. 9th International Conference, 4: 315-318.

[5] Cheddad, A., Condell, J., Curran, K., Kevitt, P.Mc., 2009, "Digital Image Steganography : Survey and Analysis of Current Methods", Signal Processing 90, 2010, 727-752. 